\title{
PCR-RFLP Analysis of TNP2 Gene in Indigenous Cattle Breeds
}

\author{
Ashish $\operatorname{Ranjan}^{1}{ }^{*}$, K.N. Raja ${ }^{1}$, Ranjana $\operatorname{Sinha}^{2}$ and I. Ganguly ${ }^{1}$ \\ ${ }^{1}$ Division of Animal Genetics and Breeding, NDRI, Karnal, 132001 (India) \\ ${ }^{2}$ Livestock Production Management, NDRI, Karnal, 132001 (India) \\ ICAR-National Dairy Research Institute, Karnal, Haryana-132001, India \\ *Corresponding author
}

\section{A B S T R A C T}

\begin{tabular}{l} 
K e y w o r d s \\
Indigenous cattle, \\
Cladogram, \\
Polymorphism, \\
PCR-RFLP, TNP2 \\
gene. \\
Article Info \\
$\begin{array}{l}\text { Accepted: } \\
\text { 06 July } 2018 \\
\text { Available Online: } \\
10 \text { August } 2018\end{array}$ \\
\hline
\end{tabular}

Keywords

Indigenous cattle, Cladogram,

Polymorphism, PCR-RFLP, TNP2

Accepted:

06 July 2018

10 August 2018

\begin{abstract}
Present study was conducted on 50 bulls and 40 male calves of Sahiwal, Tharparkar and Karan Fries cattle maintained at Artificial Breeding Research Center and Livestock Research Center, NDRI Karnal (Haryana) to identify genetic polymorphisms in TNP2 gene. A total of $1528 \mathrm{bp}$ of TNP-2 gene were studied in Bos indicus cattle breeds, which are widely distributed in Indian sub-continent. Three sets of primers for TNP2 gene on the basis of Bos Taurus sequence (Acc. No- BK_006514) were designed using Primer3 software and PCR products of 459, 483, 484 base pairs were obtained. Amplicons were custom sequenced and subjected to Clustal $\mathrm{W}$ analysis which showed nucleotide changes in non coding region in Indian cattle breeds as compared to Bos taurus. Analysis of SNPs were performed, using restriction fragment length polymorphism (PCR-RFLP), to detect nucleotide changes in the sequence as reported (g. $480 \mathrm{C}>\mathrm{T}$ and g. $1536 \mathrm{C}>\mathrm{T}$ ) in Chinese Holstein breed. Polymorphism at $480 \mathrm{C}>\mathrm{T}$ was present while for g. $1536 \mathrm{C}>\mathrm{T}$, there were absence of variability in the sampled population of Sahiwal, Tharparkar and Karan Fries cattle.
\end{abstract}

\section{Introduction}

One of the key factor for successful execution of breeding programs is the availability of best male which are selected from the existing germplasm because male have greater role in genetic improvement and up-gradation. Increasing reliability on artificial insemination (AI) techniques, for rapid and maximum genetic improvement, outstanding breeding bulls are utilized intensely. To meet the requirement of genetically superior bull and good quality frozen semen in India, a
Minimum Standard Protocol (MSP) for semen production was developed to produce frozen semen of uniform quality (DAHD\&F, 201617). However, some of the worthy males have low fertility even having standard semen parameter. Among the several reasons of infertility and sub-fertility, maturation of spermatozoa is an important factor (Foresta $e t$ al., 1992). Therefore, Genes affecting the spermatogenesis and spermatogenesis are crucial for efficient utilization of resources, maximizing production and genetic improvements. Molecular defects in these 
genes leads to impairment of interaction with ova (Lucy, 2001; Braundmeier and Miller, 2001). Transition nuclear proteins (TNPs), are most important proteins, involved in substitution of histone to protamine during spermatid nuclear transformation to remodel and adjustment of sperm nuclear chromatin to maintain stability (Mylonis et al., 2005). In TNP1 gene of Sahiwal, Tharparkar and KF, there were absence of nucleotide changes and nucleotide sequences were same as Bos taurus TNP1 gene sequence (Ranjan et al., 2017). Defects in TNP2 protein, causes acrosomal defects, incapable the spermatozoa to penetrate the zona pellucida leads to male infertility (Yu et al., 2000). TNP2 involved in chromatin condensation (Baskaran and Rao, 1990). It is localized at protamine gene cluster on 25q12-q13 (Acc.No-BK_006514) in Bos taurus (Reinhart et al., 1991). It required for the establishment of species specific morphology of sperm DNA and changes of the nuclear shaping (Oko et al., 1996; Alfonso and Kistler, 1993; Keime et al., 1992). The level of TNP2 expression of gene and protein vary among species to species. The TNP2 gene is closely linked to the PRM2 genes (Engle et al., 1992), which suggest common gene function retained by gene duplication. Inactivation of TNP2 in mice leads to failure in the PRM2 transduction and a sub fertile phenotype, showing less condensed sperm nuclei, and level of break in the DNA increases (Yu et al., 2000).

In the TNP2 gene three SNPs namely, g.269 $\mathrm{G}>\mathrm{A}$ (exon 1), g.480 $\mathrm{C}>\mathrm{T}$ (intron 1), and g.1536 C $>$ T (3'-UTR) were reported in Chinese Holstein bulls (Gao et al., 2014). The bulls with genotype TT at locus g.480 C>T had lower deformity rates than those with genotypes $\mathrm{CC}$ and $\mathrm{CT}$. But bulls with genotype CT at g.1536 C>T had higher ejaculate volumes and post-thaw cryopreserved sperm motility than those with genotype CC (Gao et al., 2014). Two SNPs has also been identified in intronic region of TNP2 in Murrah buffalo bull and their effects on mass activity, individual motility were nonsignificant (Panigrahi and Yadav, 2009). Therefore, the present study was carried out with the objective to study the genetic variability of TNP2 genes in Sahiwal, Tharparkar and Karan Fries breeds of Bos indicus cattle.

\section{Materials and Methods}

The present investigation was carried out on frozen semen of 50 breeding bull (20 Karan Fries, 20 Sahiwal and 10 Murrah bull) between 3 to 8 years old maintained at Artificial Breeding Research Centre, ICARNational Dairy Research Institute, Karnal, Haryana. Approximately 5-7 mL blood from 40 male calves (1-5calves/sire) of 9 sires (3sire/breed) was collected aseptically by jugular vein puncture in a sterile BecktonDickinson vacutainer containing $15 \%$ of 0.12 mL EDTA solution. All the experimental protocol were duly approved by the Institute's Animal Ethics Committee. Genomic DNA from blood and semen were extracted by phenol-chloroform method (Sambrook and Russell, 2001) with slight modification. Genomic DNA from blood samples was isolated by phenol-chloroform method, as described by Sambrook and Russell (2001) with little modifications. The quality, purity and concentration of genomic DNA isolated from blood and semen sample were checked by Nano drop spectrophotometry. DNA samples having the $\mathrm{OD}_{260} / \mathrm{OD}_{280}$ ratio $1.83 \pm 0.005$ were used for further work. Three sets of forward and reverse gene-specific oligonucleotide primers covered 1-500, 9111420, and 1381-1900 bp sequences of the TNP2 gene to amplify bovine TNP2 gene (NCBI Reference Sequence: Acc. NoBK_006514) were designed using Primer 3 software and got synthesized from Eurofins Genomics India Pvt. Ltd, Bangalore (Table 1). 
PCR amplification was carried out in a total volume of $25 \mu \mathrm{L}$ containing 75-100 ng DNA templates, $2.5 \mu \mathrm{L}$ of $10 \mathrm{x}$ PCR buffer with $\mathrm{MgCl}_{2}, 0.5 \mu \mathrm{L}$ of $10 \mathrm{mM}$ of dNTPs, $1 \mu \mathrm{L}$ of 10 pmol of each primer, $5 \mathrm{U}$ of Taq DNA polymerase and molecular grade $\mathrm{H}_{2} \mathrm{O}$. The PCR programmes were initial denaturation at $94^{\circ} \mathrm{C}$ for $3 \mathrm{~min}$, the cycling protocol were denaturation at $94^{\circ} \mathrm{C}$ for $30 \mathrm{sec}$, annealing temperature of $58^{\circ} \mathrm{C}$ for primer set 1 and $51.4^{\circ} \mathrm{C}$ for $30 \mathrm{sec}$ for other two primers. The extension steps were done at $72^{\circ} \mathrm{C}$ for $1 \mathrm{~min}$ followed by final extension at $72^{\circ} \mathrm{C}$ for 10 min. The numbers of cycles for primers were 32. Quality and sizes of PCR products for primers were checked on $1.5 \%$ agarose gel electrophoresis (Figure 1). PCR products were stored at $-20^{\circ} \mathrm{C}$ with proper labelling and sent for sequencing to Eurofins Genomics India Pvt. Ltd, Bangalore along with forward and reverse primers. Sequencing results were compared by clustal $\mathrm{W}$ analysis software with Bos Taurus reference sequence: Acc.NoBK_006514 (NCBI).

Based on the DNA sequence of bovine TNP2 gene (GeneBank accession no. NC_007326.4) and also on the basis of earlier report by Gao et al. (2014) two primer pairs were designed for RFLP analysis listed in table 2. One primer was synthesized from sigma while other from Eurofins Genomics India Pvt. Ltd, Bengaluru, India. The size of amplification fragment of RFLP primers were $316 \mathrm{bp}$ and $535 \mathrm{bp}$. The primer pairs with a product size of 316 and 535 bp after amplification utilized for RFLP analysis. PCR amplifications for RFLP analysis were carried out in a total volume of $25 \mu \mathrm{L}$ with same composition as above having volume $0.5 \mu \mathrm{L}$ of $10 \quad$ pmol primer concentrations. Initial denaturation was performed for 3 minutes at $94{ }^{\circ} \mathrm{C}$ followed by 32 cycles of denaturation at $94{ }^{\circ} \mathrm{C}$ for 45 seconds, annealing at $58.6{ }^{\circ} \mathrm{C}$ for 45 second for primer 1 and $54{ }^{\circ} \mathrm{C}$ for 45 second for primer 2 and elongation at $72{ }^{\circ} \mathrm{C}$ for 1 minute were performed and final extension was performed at $72{ }^{\circ} \mathrm{C}$ for 10 minutes. PCR products were checked by running gel electrophoresis with $1.5 \%$ agarose gel. All the 88 PCR amplified products for RFLP primer 1 and 2 of TNP2 gene having amplicon size 316 and 535 bp were used for digestion with $\mathrm{Hpa}$ II and Hind III restriction enzyme in $25 \mu \mathrm{L}$ of reaction mixture with amplicons $(10 \mu \mathrm{L})$, restriction enzyme $(5 U)$, buffer $(2.5 \mu \mathrm{L})$ and rest molecular grade water to detect nucleotide changes in the sequence as reported (g.480 $\mathrm{C}>\mathrm{T}$ and g.1536 $\mathrm{C}>\mathrm{T}$ ) of TNP2 Gene in Chinese Holstein cattle. The digestion with $\mathrm{RE}$ was performed for about 10 hours in the circulating water bath at $37{ }^{\circ} \mathrm{C}$. The digested products were resolved on $2.0 \%$ agarose gel by running in $1 \mathrm{x}$ TBE buffer for $1.0 \mathrm{hr}$.

\section{Results and Discussion}

A total of 1528 bp sequence of Bos indicus breeds (Sahiwal, Tharparkar, KF) TNP2 gene including 2exon and 1 intron were obtained in the present study. Obtained sequences were analyzed for making consensus sequence and detection of SNPs by using Clustal W software. For determining SNPs in TNP2 reference sequence of Bos taurus available at NCBI genome browser (http://www. ncbi.nlm.nih.gov) were aligned with sequencing results of each breeds for each targeted region using Clustal W multiple sequence alignment programme. Multiple sequence alignment of TNP2 gene sequence with sequences of all the three primers of two animals each of Sahiwal, Tharparkar and Karan Fries were done with reference sequence of Bos taurus available at NCBI genome browser (http://www.ncbi.nlm.nih. gov) for each targeted region. One nucleotide variation at the position similar to Chinese Holstein breed (g.480 C>T) was observed among the breeds studied in comparison with the Bos taurus sequence. 
BLAST analysis and Cladogram of fragment 3 of TNP2 gene

BLAST analysis for obtained sequences fragment of primer 3 of TNP2 gene was performed to find the sequence identity between various species. Bos indicus breeds Sahiwal, Tharparkar and cross breed Karan Fries showed 99\% sequence identity with Bos taurus and other species it showed 93-98\% identity.

Cladogram was prepared for exploring evolutionary relationship of TNP2 gene of different species with Sahiwal, TP and KF bulls which is illustrated in the figure 4 . Cladogram showed that Sahiwal, KF and Tharparkar breeds were related and are closer in evolutionary tree to Bos taurus than to Bubalus bubalis and Ovis Canadensis. This indicates that the TNP2 amino acid sequence is poorly conserved between indigenous cattle breeds and also among various mammals (Alfonso and Kistler, 1993).

\section{RFLP analysis for g.480 $\mathrm{C}>\mathrm{T}$ and g. 1536 $\mathrm{C}>\mathrm{T}$}

Designed and synthesized primers were not similar to primers synthesized by Gao et al. (2014). The size of amplification fragment of RFLP primers for g. $480 \mathrm{C}>\mathrm{T}$ and g. $1536 \mathrm{C}>\mathrm{T}$ were $316 \mathrm{bp}, 535 \mathrm{bp}$ utilized for PCR-RFLP analysis. All the 78 amplified products for TNP2 RFLP primers were used for digestion with Hpa II and Hind III restriction enzyme to find nucleotide change in the sequence as reported (g. $480 \mathrm{C}>\mathrm{T}$ and g. $1536 \mathrm{C}>\mathrm{T}$ ) in Chinese Holstein breed. The PCR products of TNP2 for locus g.480 C > T after digestion with Hpa II enzyme produced the following genotypes viz., CC having 228 and 88 bp fragments; CT genotype 316, 228, and $88 \mathrm{bp}$ fragments; and TT genotype have $316 \mathrm{bp}$ fragment (Figure.2). The obtained genotypes were in agreement with the DNA sequencing results and also with NEB cutterV2. In Sahiwal, Tharparkar and Karan Fries, it was observed that all the three fragment length patterns were present having fragment length of $316 \mathrm{bp}, 228 \mathrm{bp}$ and $88 \mathrm{bp}$ that indicate presence of all the genotype in sires as well as in calves of above studied breeds.

All of the 88 products for TNP2 RFLP primers having amplicon size 535bp for g. $1536 \mathrm{C}>\mathrm{T}$ were used for digestion with Hind III restriction enzyme to spot nucleotide changes in the sequence as reported in Chinese Holstein breed. The PCR products of TNP2 g. $1536 \mathrm{C}>\mathrm{T}$ locus after digestion with Hind III produced only one genotype (TT) in the sampled population of three breeds under study having 432 and 103 bp fragments (Figure.3). The obtained genotypes were also in agreement with the DNA sequencing results and also with NEB cutter V2. Zhang et al. (2015) reported earlier one primer pairs were designed and synthesized (Eurofins Genomics India Pvt. Ltd., Bengaluru, India). The size of amplification fragment of RFLP primers were $307 \mathrm{bp}$ utilized for further PCR-RFLP analysis.

\section{Inheritance pattern of TNP2 genes in Indian cattle}

In this study, 15 Karan Fries calves were selected from 7 sires and 22 Sahiwal calves from 6 sires to analyze the inheritance pattern of TNP2 gene. For TNP2 (g.1536 C>T) gene primer all sires and calves have same genotype TT indicate that the population under study were homozygous for $\mathrm{G}$ allele. While for TNP2 gene at the locus g.480 C > T all the three genotype were observed in $\mathrm{KF}$ cattle. Two KF sires having CC genotype have all the seven male calves with CC genotype, while other sire of same genotype had male calves of both CC and CT genotype. Two sires having CT genotype had two calves of CC and one calf of CT genotype. 
Table.1 TNP 2 primers sequence

\begin{tabular}{|c|l|l|c|c|}
\hline S.No & Oligo Name & \multicolumn{1}{|c|}{ Sequence(5'-3') } & sequence Covered & $\begin{array}{c}\text { Product } \\
\text { Length }\end{array}$ \\
\hline $\mathbf{1}$ & F1 & CCCCACTCTACTGGGGTCAG & $1-500$ & 459 \\
& R1 & GCCTCCTCCTCCTCTTCTG & & \\
\hline $\mathbf{2}$ & F2 & GGACTCCCCCAGAGAAGG & $911-1420$ & 484 \\
\hline & R2 & TCATGCCTCCAGATATCCAA & & \\
\hline $\mathbf{3}$ & F3 & TCTGGAGGCATGACTATTGAGA & $1381-1900$ & 495 \\
& R3 & AACGTGTGATGGCGTTTCTT & & \\
\hline
\end{tabular}

Table.2 List of primer pairs used for PCR-RFLP analysis of TNP2 gene along with Restriction Enzymes used and expected genotypes

\begin{tabular}{|c|c|c|c|c|c|}
\hline SNP & Primer sequence & $\begin{array}{l}\text { Annealing } \\
\text { Tem }\left({ }^{0} \mathrm{c}\right)\end{array}$ & $\begin{array}{l}\text { Restriction } \\
\text { Enzyme }\end{array}$ & $\begin{array}{l}\text { Incubation } \\
\text { Tem }\left({ }^{0} \mathrm{c}\right)\end{array}$ & $\begin{array}{l}\text { RE size bp / } \\
\text { genotype }\end{array}$ \\
\hline g. $480 \mathrm{C}>\mathrm{T}$ & $\begin{array}{l}\text { F: } \\
\text { TGGAGGGAAAGGTGA } \\
\text { TCAAG } \\
\text { R: } \\
\text { CCTAGCTAATCTGCC } \\
\text { GTTCG }\end{array}$ & 58.6 & HpaII & 37 & $\begin{array}{l}\text { CC: } 228 \& 88 \\
\text { CT: } 316,228 \& \\
88 \\
\text { TT: } 316\end{array}$ \\
\hline g.1536 C >T & $\begin{array}{l}\text { F: } \\
\text { ACTGGACCAATGAAG } \\
\text { CAA } \\
\text { R: } \\
\text { CTCCCTACCCAACCTC } \\
\text { TT }\end{array}$ & 54 & HindIII & 37 & $\begin{array}{l}\text { CC: } 535 \\
\text { CT: } 535,432 \& \\
103 \\
\text { TT } 432 \& 103\end{array}$ \\
\hline
\end{tabular}

Table.3 Genotype frequency for g. $480 \mathrm{C}>\mathrm{T}$ and g.1536 C $>\mathrm{T}$ of TNP2 gene in Indian cattle breeds

\begin{tabular}{|l|l|l|l|c|}
\hline SNP & Genotype & $\begin{array}{c}\text { Sahiwal } \\
\text { (36 sample) }\end{array}$ & $\begin{array}{c}\text { Karan Fries } \\
\text { (32 sample) }\end{array}$ & $\begin{array}{c}\text { Tharparkar } \\
\text { (10 sample) }\end{array}$ \\
\hline g.480 C>T & CC: $228 \& 88$ & $0.77(28)$ & $0.47(15)$ & 0.7 \\
& CT: $316,228 \& 88$ & $0.23(8)$ & $0.40(13)$ & 0.3 \\
& TT:316 & & $0.13(4)$ & \\
\hline g.1536 C>T T & CC: 535 & - & - & - \\
& CT: $535,432,103$ & - & - & - \\
& TT: 432,103 & 1.0 & 1.0 & 1.0 \\
\hline
\end{tabular}


Fig.1 Resolution of PCR primer products

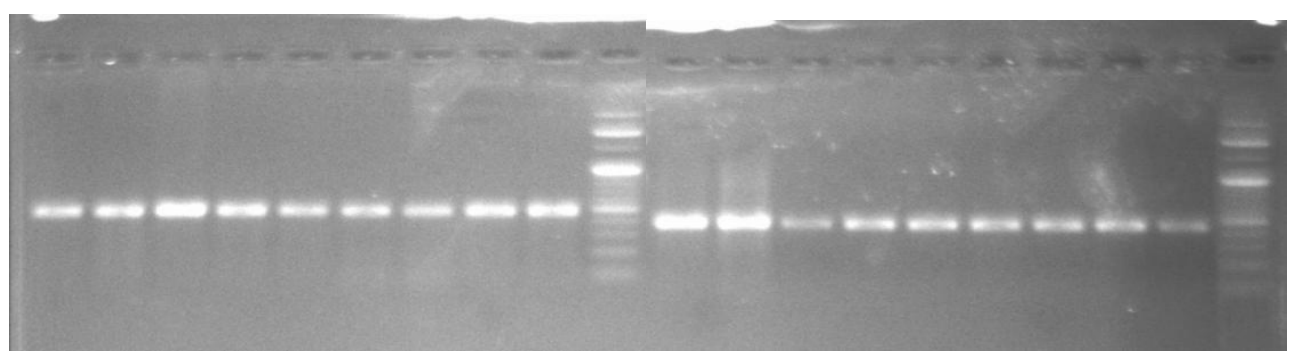

Fig.2 Resolution of PCR-RFLP primer products (for g.480 C>T)

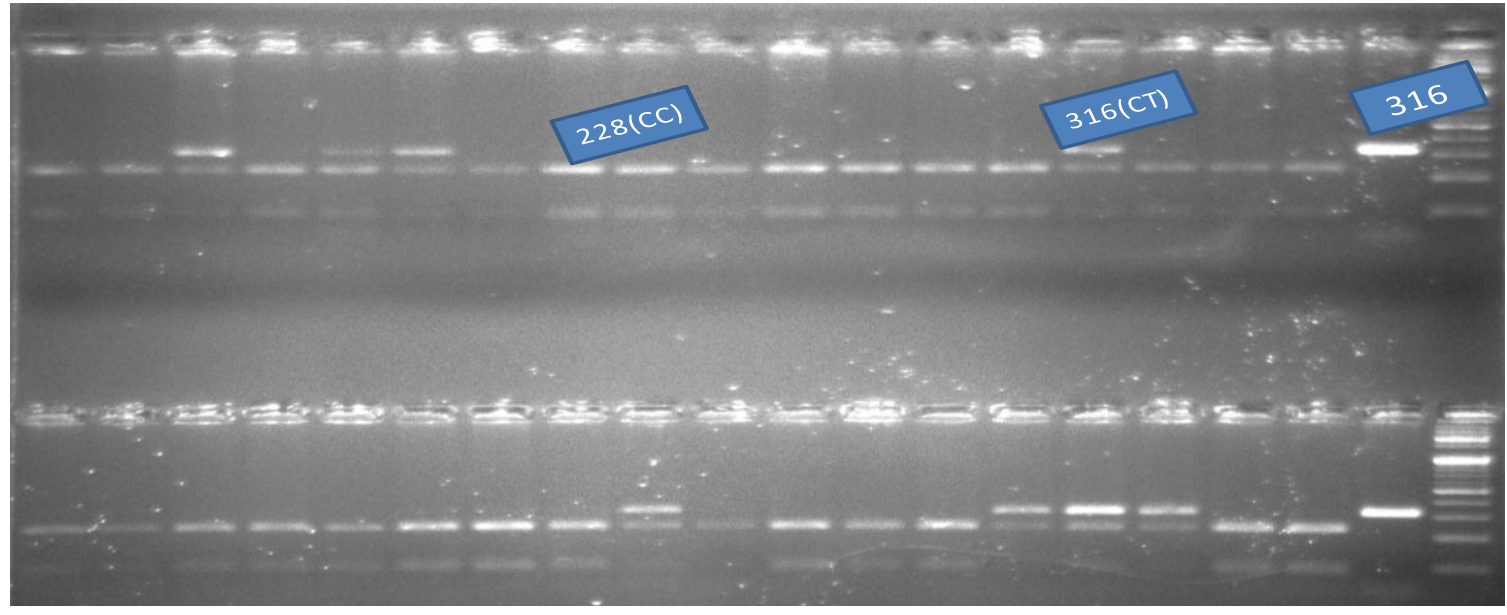

Fig.3 Resolution of PCR-RFLP primer products (g. $1536 \mathrm{C}>\mathrm{T}$ )

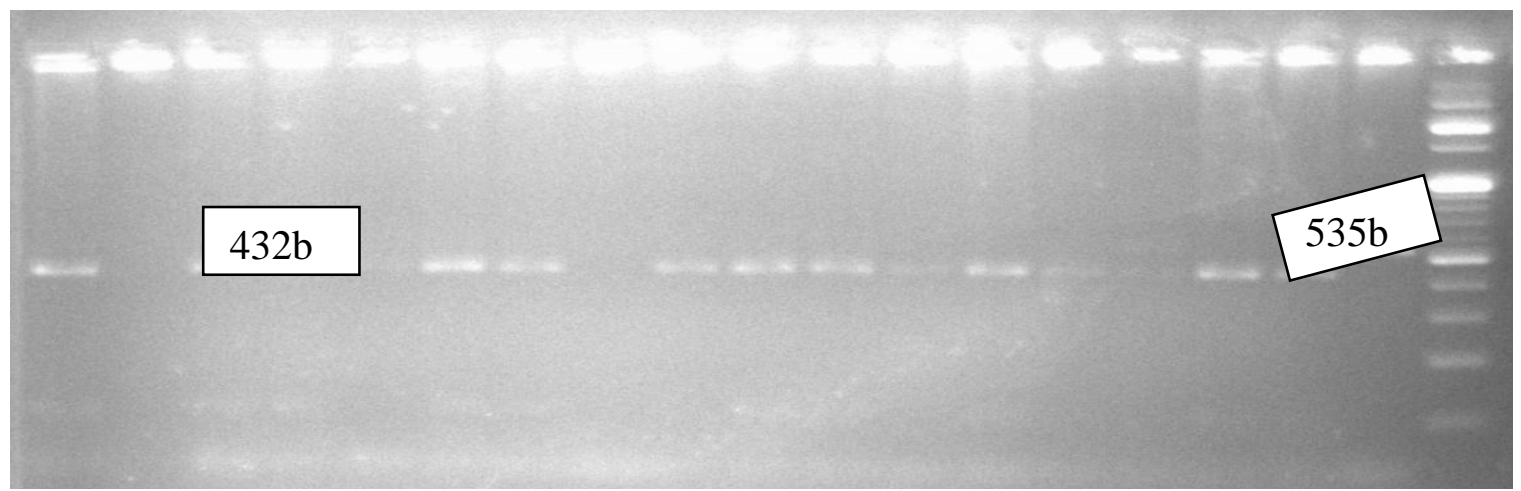

Fig.4 Cladogram of fragment 3 of TNP2 gene

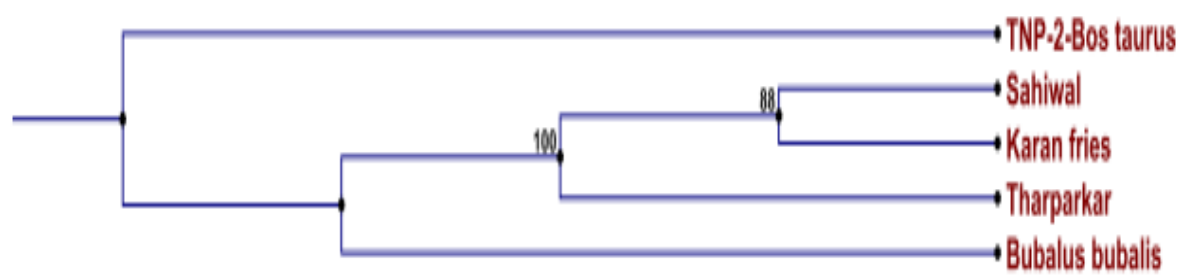


In total three sires homozygous for $\mathrm{C}$ allele at this locus had nine calves of CC genotype and one calf of CT genotype. This indicates that the other allele $\mathrm{C} / \mathrm{T}$ might have come from dam and dam may be homozygous or heterozygous for $\mathrm{C}$ or $\mathrm{T}$ allele at this locus in $\mathrm{KF}$ cattle. In Sahiwal four sires with homozygous $\mathrm{C}$ at this locus produced eleven calves of CC genotype and three calves of CT genotype. Two sires having CT genotype had one male calf of CT and seven calves of CC genotype. One sire having $\mathrm{CC}$ genotype had all calves of $\mathrm{CT}$ genotype. This inheritance pattern indicates that $\mathrm{C} / \mathrm{T}$ allele at this locus might have been inherited from maternal side. TNP2 gene (g.1536 C>T) primer 3 all sires and calves of studied breeds have same genotype i.e. TT that indicates the population under study may be fixed or homozygous for $\mathrm{T}$ allele for the studied locus.

It is concluded that the polymorphism detected in TNP2 at locus g.480 C>T observed different genotypes in Sahiwal, Tharparkar and Karan Fries, which needs to associate with the seminal parameters because TNP2gene plays a major role in sperm DNA condensation and have impact on sperm motility which affects the conception rate. To accomplish this, large numbers of bull be included from different locations for establishing the effect of different genotypes of TNP 2 gene on semen characteristics for the production of semen having better quality parameters to increase the conception and thereby decreasing the infertility.

Absence of nucleotide change at g. $1536 \mathrm{C}>\mathrm{T}$ in Karan Fries cattle which is a cross of HF and Tharparkar breed indicates that sample population is free from any mutation for the loci and nucleotides are same as indigenous cattle breeds.

\section{References}

Alfonso, P.J. and Kistler, W.S. 1993. Immunohistochemical localization of spermatid nuclear transition protein 2 in the testes of rats and mice. Biol. Reprod. 48: 522-529.

Baskaran, R. and Rao, M.R. 1990. Interaction of spermatid-specific protein TP2 with nucleic acids, in vitro: a comparative study with TP1. J. Biol. Chem. 21: 039-047.

Braundmeier, A.G. and Miller, D.G. 2001.The search is on: Finding Accurate molecular markers of male fertility. J Dairy Sci., 84: 1915-1925.

Department of Animal Husbandry Dairying and Fisheries. Govt. of India. (DAHD and F, GoI. 2016-17.

Engel, W., Keime, S., Kremling, H., Hameiste, H. and Schluter, G. 1992. The genes for protamine 1 and 2 (PRM1 and PRM2) and transition protein 2 (TNP2) are closely linked in the mammalian genome. Cytogenet Cell Genet 61: 158-159.

Forestra, C., Zorzi, M., Rossato, M. and Varotto, A. 1992. Sperm nuclear instability and staining with aniline blue: abnormal persistence of histones in spermatozoa of infertile men. Int. $J$. Androl. 15: 330-337.

Gao, Q., Ju, Z., Zhang, Y., Huang, J., Zhang, X., Qi, C., Li, J., Zhong, J., Li, G. and Wang, C. (2014). Association of TNP2 Gene polymorphisms of the btamiR-154 target site with the semen quality traits of Chinese Holstein Bulls. Plos one 9(1): e84355.

Keime, S., Heitland, K. and Kumm, S. 1992. Characterization of four genes encoding basic proteins of the porcine spermatid nucleus and close linkage of three of them. Biol Chem Hoppe-Seyler. 373: 261-270.

Lucy, M.C. 2001. Reproductive loss in high-producing dairy cattle: where will it end. J. Dairy Sci. pp $1277-$ 1293.

Mylonis I, Drosou V, Brancorsini S, 
Nikolakaki E, Sassone-Corsi P, Giannakouros T. 2004. Temporal association of protamine 1 with the inner nuclear membrane protein lamin B receptor during spermiogenesis. $J$ Biol Chem., 279: 11626-31.

Alfonso, P.J. and Kistler, W.S. 1993. Immunohistochemical localization of spermatid nuclear transition protein 2 in the testes of rats and mice. Biol. Reprod. 48: 522-529.

Oko, R.J., Jando, V. and Wagner, C.L. 1996. Chromatin reorganization in rat spermatids during the disappearance of testis-specific histone, $\mathrm{H} 1 \mathrm{t}$, and the appearance of transition proteins TP1 and TP2. Biol. Reprod 54: 1141-1157.

Panigrahi, S.K. and Yadav, B.R. 2009. Polymorphism in TNP-1gene of Murrah buffalo bulls. African Journal of Biotechnology. 9(43): 7224-7229, 2010.

Ranjan, A., Raja, K.N., Sinha, R., Ganguly, I., Gupta, I.D., Bhakat, M. and Mohanty, T.K. 2017. Sequence characterization and SNP identification of TNP1 gene in Indian cattle breeds. Doi: 10.18805/ ijar.v0iOF.8492.

Reinhart, N., Kremling, H., Luerssen, H., Adham, I.M. and Engel, W. 1991.
Characterization of a gene encoding a basic protein of the spermatid nucleus, TNP2, and its close linkage to the protaminegenes in the bull. Biol Chem Hoppe-Seyler 372: 431-436.

Sambrook, J. and Russell, W. D. 2001. Molecular cloning.A laboratory manual $1^{\text {st }}$ volume. Cold Spring Harbor Laboratory Press, New York: pp. 1.32-1.34 and 8.14.

Yu, Y.E., Zhang, Y., Unni, E., Shirley, C.R., Deng, J.M., Russell, L.D., Weil, M.M., Behringer, R.R. and Meistrich, M.L. 2000. Abnormal spermatogenesis and reduced fertility in transition nuclear protein 1deficient mice. Proceedings of the National Academy of Sciences of the United States of America. 97(9): 46834688.

Zhang, S., Zhang, Y., Yang, C., Zhang, W., Ju, Z., Wang, X., Jiang, Q., Sun,Y., J Huang, J., Zhong, J. and Wang, C. 2015. TNP1 functional SNPs in btamiR-532 and bta-miR-204 target sites are associated with semen quality traits in Chinese Holstein bulls. Biolreprod.

\section{How to cite this article:}

Ashish Ranjan, Raja, K.N., Ranjana Sinha and Ganguly, I. 2018. PCR-RFLP Analysis of TNP2 Gene in Indigenous Cattle Breeds. Int.J.Curr.Microbiol.ATurkeypp.Sci. 7(08): 775-782. doi: https://doi.org/10.20546/ijcmas.2018.708.086 